\title{
Social Responsibility: A Case Study of Women Coffee Growers in a Peripheral Region of Colombia
}

\author{
Yenny Díaz ${ }^{1}$, Juan M. Andrade ${ }^{2}$, Elías Ramírez ${ }^{3}$ \\ ${ }^{1}$ Corporación Unificada Nacional - CUN, Colombia \\ ${ }^{2}$ Corporación Universitaria Minuto de Dios - Uniminuto, Colombia \\ ${ }^{3}$ Universidad de Surcolombiana - Usco, Colombia
}

\begin{abstract}
The objective of this article is to show the practices of social responsibility in women belonging to organizations that produce differentiated coffees in a peripheral region of Colombia. In this regard, a quantitative, descriptive, and cross-sectional investigation was carried out, for which a model of its own was designed to characterize said practices from four dimensions: environment, society, values, transparency and government and labour matters. A questionnaire-type instrument with a Likert scale was applied to 430 women. Regarding the results, it was found that more than half of the women in the associations $(58.7 \%)$ perceive actions related to management in the margin of social responsibility. Dimensions such as Values, Transparency and Governance (VTG), Environment (E) and Society (S), have a rating higher than $50 \%$; however, the Labour Things (LT) dimension obtained the lowest percentage rating $(\mathbf{4 7 . 6 \% )}$.
\end{abstract}

Keywords - Social responsibility, women, coffee organizations.

DOI: $10.18421 /$ TEM104-28

https://doi.org/10.18421/TEM104-28

Corresponding author: Juan M. Andrade,

Corporación Universitaria Minuto de Dios - Uniminuto,

Colombia.

Email: jandradenav@uniminuto.edu.co

Received: 16 July 2021.

Revised: 04 October 2021.

Accepted: 11 October 2021.

Published: 26 November 2021.

(c))BY-NC-ND C 2021 Yenny Díaz, Juan M. Andrade \& Elías Ramírez; published by UIKTEN. This work is licensed under the Creative Commons Attribution-NonCommercial-NoDerivs 4.0 License.

The article is published with Open Access at www.temjournal.com

\section{Introduction}

Coffee activity in the world, and especially in Colombia, is a sector traditionally dominated by men; However, it has undergone significant changes in recent years, since it begins to make women visible as a fundamental part of its growth and strengthening. However, their presence and role are still oriented to traditional dynamics, where women have a support figure for men.

The strategies and practices promoted towards women to revive the demand for coffee today are a response to a market dynamic from marketing, and not from the intention of more equitable, fair, and inclusive markets. For this reason, leadership from the perspective, capacity for persuasion and joint decision-making have allowed women from the associativity to empower themselves and take part in the processes of strengthening and coffee production, despite the barriers.

In spite of the above, the concept of continuous diffuse and not very clear social responsibility within the sector, the joint practices of the certification and seals processes, has allowed them to guide their actions, and the development of specific strategies from the framework of the RS has responded immediately to specific situations. Although there is a talk of more equitable and inclusive markets, there are still gaps in the sector related to the context and participation of women in a sector where the patriarchal structure prevails. Despite the existence of projects that promote the idea of guaranteeing gender equality, women's working conditions are maintained or precarious, given the persistence of historical elements such as machismo and patriarchy [1].

The efforts are focused on improving production and the inclusion of women for the growth of the sector, but it denotes limitations in the recognition of the producer from its leading role, its conditions, and ideals in the rural context. In this sense, studies carried out at the departmental level, highlight the 
social and solidarity associative work as a facilitator for the development of productive projects that allows them to improve economic income for women [2], but not of the conditions and characteristics of empowerment and leadership possessed by women coffee growers.

Therefore, it is necessary to inquire about the characteristics of the social responsibility exercised by women in the sector, to generate a central perspective on the development and achievement of access to differentiated markets, strengthening of producer associations, responsible practices, among other Although there are no specific guidelines related to social responsibility in the framework of the coffee sector. Coffee growing, through the changing dynamics of markets, social and environmental aspects, has become aware of the importance and promotion of a series of criteria and standards for the production and commercialization of grain, such as sustainable certifications according to the category, friendly with the environment, social content, organic coffee, and fair trade.

\section{Literature Review}

\subsection{Social Responsibility}

Social responsibility has been established to the extent that organizations and society are interwoven, where the latter has certain expectations about the behavior and results of the organization [3]. So much so, that its social performance refers to the configuration of the principles of social responsibility, policies, programs, processes, and results of the social response that the organization has before society and that shows its relationship with it. Likewise, more and more social responsibility establishes a relationship with the economic and financial performance of organizations and their operationalization [4], [5].

Carroll [6] allows us to understand Social Responsibility from four perspectives; economic, legal, or legal, ethical, and philanthropic, where the model cannot be covered sequentially or progressively, but comprehensively regardless of the role or core of the organization. That is why, even though social responsibility is attributed to large companies, there is a strong tendency in small companies and organizations to speak and propose particularities from economic, social, and environmental aspects, from the framework of social responsibility [7], whose purpose is to contribute to sustainable development [8]. Therefore, organizations and their stakeholders see the importance of a socially responsible act.

Lantos [9], for his part, exposes four focuses of action for SR: vision of profit generation as a single purpose, vision of profit generation in a limited area, vision of social welfare and vision of a company at the service of the community.

The third classification was established by Garriga and Melé [10], around four theoretical currents: instrumental, integrative, political, and ethical (see Table 1).

Table 1. Theory of Social Responsibility

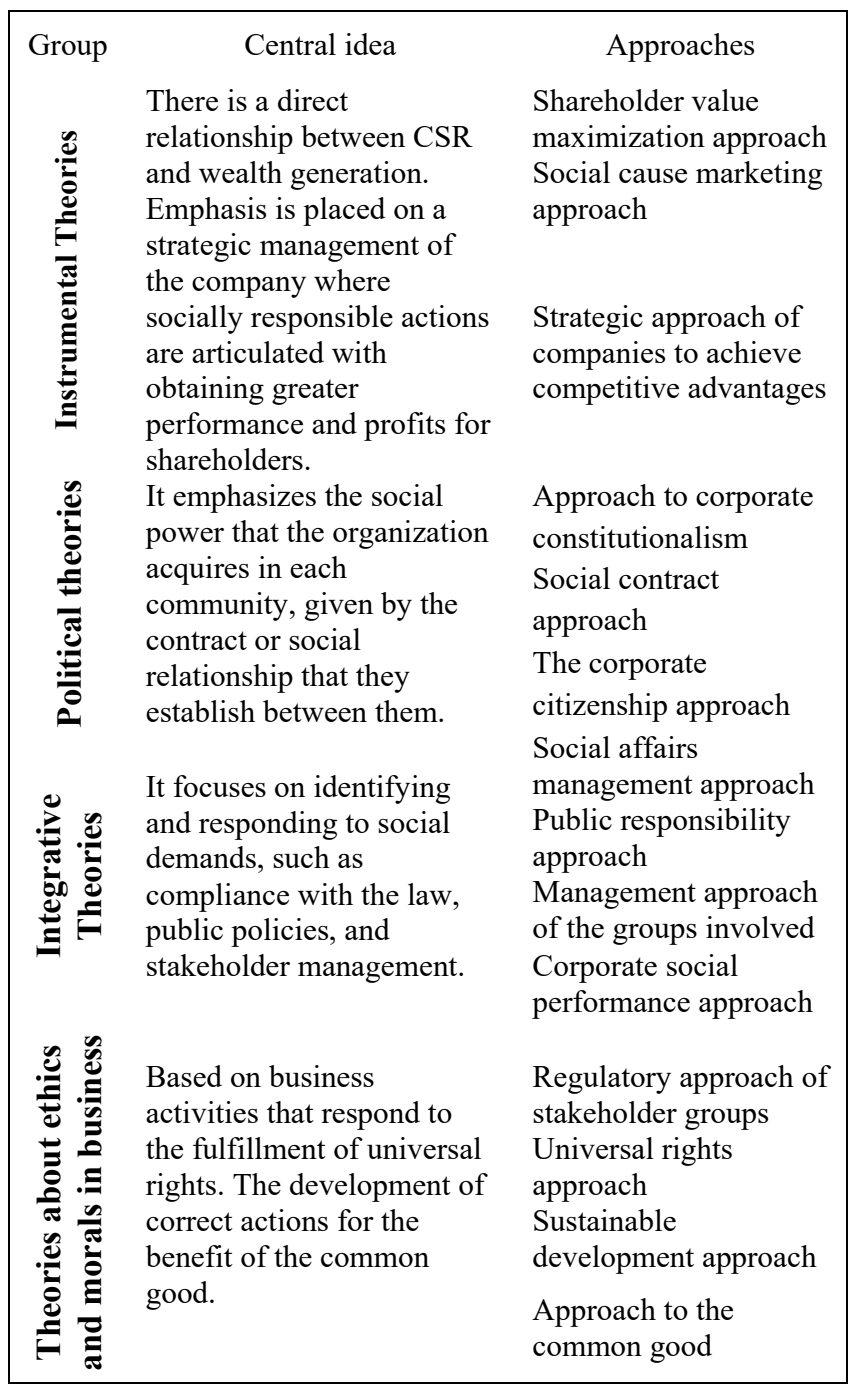

\subsection{Social Responsibility and Coffee}

The coffee sector has been linking social responsibility through the systematic development of policies, programs and practices for the production, distribution, and marketing of coffee. The associations linked to this production chain have also adhered to the basic principles of management through decision-making that are consistent with the basic principles of management, including those unconventional study bodies.

The generation of economic value and competitiveness, the efficient use of natural resources and the strengthening of the social fabric, have been the reasons why a sector approach to social responsibility has been developed [11]. For example, 
terms such as "sustainable coffee" have been used within the sector to mention the importance of the use of agricultural methods that allow profitability to the coffee grower and good health, with minimal damage to the environment [12].

Thus, the use of quality certifications by coffee producers has been one of the means to promote and show social responsibility and coffee sustainability, whose objective is to achieve responsible production and origin, as well as social and environmental conditions. adequate. Also, there are more and more certifications and codes of conduct issued by specialized and authorized centers in the sector, related to this management model, especially those associated with environmental aspects.

Now, the involvement of women in the sector and their affirmative response to social responsibility is a bet that has been existing through the struggle for visibility and recognition from the culturally designated functions within their feminine social role, such as their role within the value chain of the sector [1]. Although, the presence and role of women in coffee growing has become different [13], it is still classified as "support from the coffee grower" and despite the practices and strategies to revive the demand for coffee from the gender equity, there are gaps related to the context and participation of women in a sector where the patriarchal structure prevails.

Even though in recent years there have been studies that examine the practices of social responsibility and its relationship with gender in different fields of social and economic life [14], [15], [16], [17], [18], and these are almost non-existent in peripheral countries, especially when addressed in unconventional organizational contexts.

Based on this investigative work seeks to describe the perceptions of the principles of social responsibility established in associations of women coffee growers, as well as their sociodemographic conditions, considering that there are few investigations regarding women, their community, and its role in the coffee sector and in the margin of social responsibility.

\section{Materials and Methods}

The research methodology was constituted in five stages: the first mentions the approach in which it is developed, the second the population group and the sample, the third describes the quantitative instruments applied, the operationalization of the variables and study dimensions, the fourth considers the ethical considerations and, finally, the fifth presents the criteria for the analysis of the information.

\subsection{Approach}

The research was approached from a quantitative perspective due to the nature of the data obtained, descriptive in that it seeks to describe the phenomenon of SR and is cross-sectional since it collects information in a single moment [19], whose objective is to investigate and describe the dimensions of social responsibility in an unconventional organization associated with the coffee activity, specifically in the associations of women producers of special and differentiated coffee in a peripheral region of Colombia.

\subsection{Population and Sample}

The population corresponds to the women who make up the associations of coffee producers in a peripheral region of Colombia. The sample used was non-probabilistic, specifically a convenience sampling, in which 450 questionnaires were applied to women from ten coffee associations, with extensive experience in the production of traditional and differentiated coffee. In general, women of legal age who were formally linked to the organizations and who voluntarily participated in the study were selected.

\subsection{Instruments and Operationalization}

The first survey was carried out to the associations of women coffee growers, to identify sociodemographic variables such as personal, family and land tenure data and its production.

On the other hand, the instrument for measuring social responsibility in associations used corresponded to the proposal of Andrade et al. [20], used for the coffee context. The questionnaire has 29 items derived from 4 dimensions: values, transparency, and governance (VTG), labor issues (LA), environment (MA), and society (S) (see Table 2). For all items, people indicated their perception on a five-point Likert-type scale, where one (1) means totally disagree and five (5) means totally agree (see Table 2). 
Table 2. Questionnaire variables

\begin{tabular}{|c|c|c|}
\hline \multirow[t]{10}{*}{ Variable } & Dimension & Scope \\
\hline & Socioeconomic & $\begin{array}{l}\text { Classification in strata of } \\
\text { housing conditions according to } \\
\text { access to services and goods. }\end{array}$ \\
\hline & Education level & $\begin{array}{l}\text { Understand the formal education } \\
\text { that the producer has }\end{array}$ \\
\hline & Age & $\begin{array}{l}\text { Elapsed time in years of the } \\
\text { person's existence }\end{array}$ \\
\hline & Dependents & $\begin{array}{l}\text { Number of economically } \\
\text { dependent people }\end{array}$ \\
\hline & $\begin{array}{l}\text { Head of the } \\
\text { family }\end{array}$ & $\begin{array}{l}\text { Condition that establishes being } \\
\text { in charge or being directly } \\
\text { responsible for the rest of the } \\
\text { household members. }\end{array}$ \\
\hline & $\begin{array}{l}\text { Conformation of } \\
\text { economic income }\end{array}$ & $\begin{array}{l}\text { Source of economic income for } \\
\text { the family }\end{array}$ \\
\hline & Housing tenure & $\begin{array}{l}\text { Relationship of the person with } \\
\text { the home }\end{array}$ \\
\hline & $\begin{array}{l}\text { Housing } \\
\text { distribution }\end{array}$ & $\begin{array}{l}\text { Number of physical spaces } \\
\text { divided or formed in the house }\end{array}$ \\
\hline & $\begin{array}{l}\text { Housing } \\
\text { materials }\end{array}$ & $\begin{array}{l}\text { Predominant materials of which } \\
\text { the house is made }\end{array}$ \\
\hline \multirow{11}{*}{ 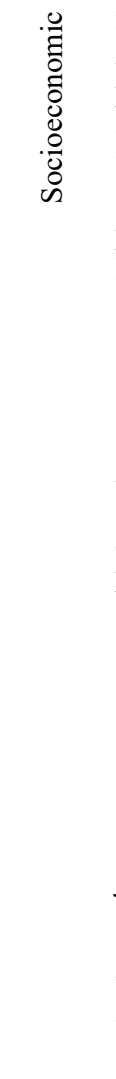 } & $\begin{array}{l}\text { Access to the } \\
\text { property }\end{array}$ & $\begin{array}{l}\text { Type of road that the property } \\
\text { has to access it. }\end{array}$ \\
\hline & Property tenure & $\begin{array}{l}\text { Relationship of the person with } \\
\text { the property }\end{array}$ \\
\hline & $\begin{array}{l}\text { Extension of the } \\
\text { property }\end{array}$ & $\begin{array}{l}\text { Number of hectares of the } \\
\text { property }\end{array}$ \\
\hline & $\begin{array}{l}\text { Productive use } \\
\text { extension }\end{array}$ & $\begin{array}{l}\text { Number of hectares of the } \\
\text { property in productive use }\end{array}$ \\
\hline & $\begin{array}{l}\text { Coffee use } \\
\text { extension }\end{array}$ & $\begin{array}{l}\text { Extension of use of Number of } \\
\text { hectares of the property in use } \\
\text { only for coffee cultivation }\end{array}$ \\
\hline & $\begin{array}{l}\text { Type of coffee } \\
\text { you produce }\end{array}$ & Kind of coffee that it produces \\
\hline & $\begin{array}{l}\text { Annual } \\
\text { production } \\
\text { income }\end{array}$ & $\begin{array}{l}\text { Sum of average income } \\
\text { generated by coffee production } \\
\text { in the year (Colombian Pesos - } \\
\text { COP) }\end{array}$ \\
\hline & $\begin{array}{l}\text { Seal or } \\
\text { certifications }\end{array}$ & $\begin{array}{l}\text { Stamps, code of conduct and } \\
\text { certifications that the respondent } \\
\text { possesses. }\end{array}$ \\
\hline & Client & $\begin{array}{l}\text { Type of buyer or customer who } \\
\text { sells the production to you }\end{array}$ \\
\hline & job & $\begin{array}{l}\text { Amount of employment } \\
\text { generated in production } \\
\text { (average) }\end{array}$ \\
\hline & $\begin{array}{l}\text { Values, } \\
\text { transparency, and } \\
\text { governance } \\
\text { (VTG) }\end{array}$ & $\begin{array}{l}\text { It is related to the affinity with } \\
\text { certain values and ethical } \\
\text { principles, management } \\
\text { practices, self-regulation of } \\
\text { behavior and transparent links } \\
\text { with the community. }\end{array}$ \\
\hline \multirow{3}{*}{ 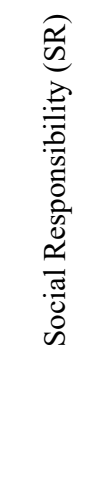 } & $\begin{array}{l}\text { Laboral things } \\
(\mathrm{LT})\end{array}$ & $\begin{array}{l}\text { Corresponds to internal policies } \\
\text { and practices oriented to work or } \\
\text { associativity. }\end{array}$ \\
\hline & Environment (E) & $\begin{array}{l}\text { Adoption of an integrated } \\
\text { approach aimed at mitigating } \\
\text { direct and indirect environmental } \\
\text { implications. }\end{array}$ \\
\hline & Society (S) & $\begin{array}{l}\text { They are related to initiatives } \\
\text { that stimulate a permanent } \\
\text { relationship with interest groups } \\
\text { (society), leadership and human } \\
\text { rights, among others. }\end{array}$ \\
\hline
\end{tabular}

Source: Own elaboration
Cronbach's Alpha was performed for the Social Responsibility variable to establish an acceptable level of confidence for the study, obtaining excellent consistency $(\alpha=0.91)$. Also, a detailed analysis of the reliability of the dimensions of the instrument is used, whose results were: environment with 9 elements was 0.90 , society with 7 elements was 0.88 , values, transparency, and government with 7 elements was 0.88 , and labour things with 6 items was 0.92 . As can be seen, in all cases the coefficients represent an adequate index of convergence (see Table 3).

Table 3. Reliability of the dimensions of the questionnaire

\begin{tabular}{|lcc|}
\hline \multicolumn{1}{|c}{ Reliability statistics } & Cronbach's alpha & Elements \\
Environment - E & $\alpha=0,90$ & 9 \\
Society - S & $\alpha=0,88$ & 7 \\
Values, transparency, and & $\alpha=0,88$ & 7 \\
governance -VTG & $\alpha=0,92$ & 6 \\
\hline Laboral things - LT &
\end{tabular}

Source: Own elaboration

\subsection{Ethical Considerations}

It is a risk-free investigation, which does not imply experimental manipulation, and that all procedures were with the prior voluntary consent of the participants. It is approached respecting the dignity, well-being and rights of the people who participated and knowing the legal norms and professional standards that regulate the conduct of the investigation.

\subsection{Analysis of Data}

The data obtained were entered into a matrix constructed with Microsoft's Excel program, in an ordered manner, and the corresponding values were assigned. Then, they are transferred to the statistical package for the social sciences (Statistical Package for the Social Sciences, SPSS version 24) to process the information.

\section{Results}

The producers belong to legally registered coffee associations, whose main income is the cultivation of coffee. Close to half $(48 \%)$ are heads of household and have between 1 and 12 dependents between adults and minors (92\%). The coffee-growing women of Huila have ages ranging between 26 and 80 years. $68.5 \%$ have attended up to fifth (5th) of primary school and in a lower percentage $(6.3 \%)$, they have technical and university academic degrees.

In relation to the characteristics of housing and land, most of which are located in the same 
geographical area, they belong to socioeconomic strata $1(68.5 \%)$ and $2(31 \%)$ and have most of the services; energy (97\%), aqueduct (83\%), gas $(57 \%)$, telephone network $(68 \%)$ and internet $(6 \%)$. Some of these homes do not have a bathroom (20\%) and a kitchen $(13 \%)$. The houses are built mostly in Bahareque materials (52\%) and zinc (89\%).

$53 \%$ of the properties are solely owned by women. $59 \%$ have farms of 1 to 5 hectares dedicated $100 \%$ for the exclusive use of coffee. $39 \%$ of them produce specialty coffee and $69 \%$ traditional or standard coffee. Faced with certifications, women acquire the Fair Trade-FLO (37\%), interested in fair trade for small producers and access to equitable markets. Codes of conduct such as $4 \mathrm{C}$ that stipulate criteria applicable to the sustainable production, processing and marketing of green coffee (19\%). Others such as UTZ certified (14\%), Rainforest Alliance (9\%), C.A.F.E practices $(4 \%)$, Certified Organic (3\%) and Nespresso AAA (1\%), are also acquired.

Regarding the sale of coffee beans, women coffee growers are interested in supplying it to their local cooperative $(83 \%)$, to individuals $(42 \%)$ and to a lesser extent to the association they represent (14\%).

Subsequently, the variable social responsibility in associations has an average of 4.03. Its dimensions have an arithmetic average that varies between 3.9 and 4.1. The variance of the variable as well as the subscales are not significant, since the measure of dispersion around the mean between the groups does not have an important difference (see Table 4).

Table 4. Descriptive Analysis Social Responsibility

\begin{tabular}{|c|c|c|c|c|c|}
\hline & $\begin{array}{c}\text { Values, } \\
\text { Transparency } \\
\text { and } \\
\text { Government }\end{array}$ & $\begin{array}{c}\text { Laboral } \\
\text { things }\end{array}$ & Environment & Society & $S R$ \\
\hline Average & 4,1337 & 3,9021 & 3,9767 & 4,1159 & 4,0322 \\
\hline Median & 4,2500 & 3,8889 & 4,0000 & 4,2857 & 4,0800 \\
\hline $\begin{array}{l}\text { Standard } \\
\text { deviation }\end{array}$ & ,60271 & 63548 & ,75691 & ,67624 &, 55632 \\
\hline Variance & ,363 & ,404 & ,573 & ,457 & ,309 \\
\hline
\end{tabular}

Source: Own elaboration

Faced with the descriptive analysis, it is identified that more than half of the women in the associations (58.7\%) perceive actions related to management in the margin of social responsibility. Dimensions such as Values, Transparency and Governance (VTG), Environment (E) and Society (S), have a rating greater than 50\% (see Table 5). However, the Labor Things dimension (LT) obtains the lowest percentage rating $(47.6 \%)$
Table 5. Descriptive Analysis Social Responsibility

\begin{tabular}{|cccccc|}
\hline & VTG & LT & E & S & SR \\
$\mathbf{1 - 2}$ & 4.9 & 9.1 & 9.1 & 7 & 6.3 \\
$\mathbf{3}$ & 28 & 43.4 & 34.3 & 25.2 & 35 \\
$\mathbf{4 - 5}$ & 67.1 & 47.6 & 56.6 & 67.8 & 58.7 \\
\hline
\end{tabular}

Source: Own elaboration

\section{Discussion}

Women have always been and participated in rural contexts, including coffee production. However, they have had little representation in marketing, export or management and decision-making jobs; Well, according to Rodríguez [13], a patriarchal model persists in the general structure of the sector.

The collectivities taken in the investigation, although they are legally constituted, have undergone transformations from the organizational and economic structure, even from the permanence and sustainability of the associates. According to them, there are various situations, and they conclude that their greatest barrier has been the low acceptance of their spouses or partners and of society for the development of their activity.

On the other hand, although for some of the women, the association represents a welfare dynamic on the part of the state and contributing organizations, many consider that the communities make visible the role of women in the sector and contribute to gender equality and equity, making that they empower themselves in the sector, in the territory and in their families. However, the inclusion of women in the sector independently, autonomously and leader of processes has adverse implications in the traditional conception of women and family, which breaks mechanisms of social control, due to a marked significance in gender roles [21].

Now, about half of the women in the associations are heads of household (48\%), they are between 26 and 80 years old, where $62 \%$ are over 50 years old. An important indicator for the government and the coffee and agricultural institutions on the generational change, since fewer young people are linked to this productive activity, given the different changes in the sector and the territory at an economic, environmental, and social level, and the lack of linkage mechanisms for this population to strengthen the coffee identity [22].

Regarding the educational level, only $6.3 \%$ have accessed a higher education, as a technical, technological or university professional. The shortage in labour and the significance of the female role, has made them accompany the processes of the sector since their childhood, in tasks such as caring for their siblings and children, domestic chores and feeding workers, dissociating them from educational 
settings, thus such as the difficulty of road access and extreme poverty.

However, the houses where women live have unfavorable conditions for some. More than $20 \%$ of the women do not have toilets, $46 \%$ have dirt floors and $60 \%$ have walls between wood and wattle. About $10 \%$ do not have energy or aqueduct, $43 \%$ do not have gas. Although the programs and institutions linked to the strategies and support these associations by the state and other organizations provide training through web pages and profiles on social networks for the commercialization and marketing of coffee, only $6 \%$ of women have internet.

$47 \%$ of the associated women do not own the property where they grow coffee, which is their main income. Women recognize the need to own the land, to feel autonomy in the production and marketing of coffee. Important changes in the history of women coffee growers have been linked to access to economic resources, educational processes, and land tenure [1], [13].

There is little recognition of the typification, class, or criteria to identify the specialty coffee of the standard in associated women. However, when talking in terms of overpricing coffee, women associate it with "special coffee" [23]. Burgos [24] refers that in Colombia there is a potential in special arabica coffees, but there is a strong tendency for these women to produce standard coffee $(61 \%)$, even though more than half have a certification, linking it in the certification processes of agricultural production that emerged as a green market strategy.

On the other hand, the associations were identified with concepts, principles, and practices in social responsibility. Martínez et al. [25] in their study, state that a participation of women in the decisionmaking of associations is reflected is leading to Social Responsibility in their way of acting.

Actions against the dimensions of values, transparency, government and society are the ones that are promoted the most by associations, and it is not surprising, given the principles of the solidarity economy that they represent. For example, within the society dimension, associations seek to get involved in solutions to some community problems related to rural and sustainable development [8]. Specific issues such as generational change, women's leadership, market dynamics, among others, have allowed taking important initiatives, which are compacted with previous studies such as Burgos [24], who reaffirms that the sector in Colombia is a potential solution to these different problems, especially in the generation of employment and generational change.

Situations such as the fight against inequality gaps in a sector dominated by men is one of the constant and similar actions in all associations, ranging from awareness campaigns for women, to management of family training programs and psychological, to promote the leadership of women and the change or transformation of their role -Awareness of traditional roles.

Faced with the environmental dimension, the associations guide actions aimed at the promotion and internalization of friendly habits with the environment, given the promotion of the use of nontoxic products, nor harmful to the environment, including the use of water and energy from the responsible consumption.

Regarding the labor issues dimension, women perceive few activities related or directed to formal work, legal norms, and associativity. Although the associations manage the education and training of their associates through relationships with different institutions, the latter are mostly limited to technical and commercial strengthening.

Finally, it can be mentioned that the women's coffee-growing associations promote principles and practices of social responsibility from the community in a timely manner, despite the problems and resistance to the empowerment of women by men and society. The contribution in the productive and economic part, in the social and environmental aspects, as well as in linking the production of specialty coffees through compliance with the certification requirements, has been developed as a management strategy in the associations. However, the lack of a strategic approach to the sector and the associations from the perspective of social responsibility continues to reinforce the traditional thinking where there is only a general concern for the economic aspect.

\section{Conclusions}

Within the conclusions of the study, there is a marked perception of men as a barrier or potential opponent of the involvement and participation of women in the development of the coffee sector. Family and social dynamics are still based on a patriarchal model, in which women have specific functions in the home and are only thought from within the sector, as support in some processes.

For some women and men (couples), women's associations are a means that allows them to obtain personal benefits immediately and they see it within a welfare dynamic, which may be one of the reasons why associations experience a rotation of associates or decrease in associated women. However, there is a strong perception rooted in the visibility of women in the coffee sector through this type of organization.

Although the associations are legally formed, most do not sell what they produce through them, but prefer private clients such as cooperatives of coffee 
growers and private agents, evidencing the need to strengthen the cohesion and organization of the associations.

There are specific initiatives to specific problems from the social responsibility model, framed within the responsible business and shared value, which help the dynamics of the associations and the durability and sustainability of the coffee business.

Women leaders have reached high levels of moral development, transparency, and ethical behavior, through a fair and synchronized vision of the needs of their followers and other stakeholders, generating an image of trust, identification, and adoption of their behavioral model.

There is a feeling of reciprocity between leaders and followers, generating individual considerations regarding care, empathy, providing challenges and opportunities for each one, which are outlined in actions to strengthen the association.

Public and private institutions and organizations have been strong allies in the empowerment and strengthening of women's coffee-growing associations, contributing significantly to education and cohesion processes.

It is necessary to implement strategies that allow the consolidation of associations of women coffee growers in the municipalities where they start their commitment as a group. As well, routes of attention to the violation of rights and lines of research that tend to know the dynamics immersed at the individual, family, and social level, as lines guided to practices developed from the technical processes.

Finally, this study presents a model of analysis and approach to characterize the practices of social responsibility in coffee producing organizations made up of women in a peripheral region of Colombia. It is necessary to replicate the instrument in other organizations to evaluate its performance, especially in this type of unconventional organizations.

\section{References}

[1]. Lombo, M. (2013). Institucionalización del género: Políticas públicas, escalas sociales y representaciones sobre mujeres cafeteras. Estudio de caso en el Colegio, Cundinamarca (tesis de maestría). Bogotá, Colombia: Universidad Nacional de Colombia.

[2]. Torrente Castro, W. (2016). Estudio de caso en la asociación de mujeres cafeteras del Occidente del Huila, municipio de La Plata. Á. Acevedo-Osorio y J. Martínez-Collazos (comps.),(2016). La agricultura familiar en Colombia. Estudios de caso desde la multifuncionalidad y su aporte a la paz, 121-142.

[3]. Wood, D. J. (1991). Corporate social performance revisited. Academy of management review, 16(4), 691-718.
[4]. de Oliveira Filho, M. L., \& Abadía, J. M. M. (2013). El desempeño económico financiero $\mathrm{y}$ responsabilidad social corporativa Petrobrás versus Repsol. Contaduría y administración, 58(1), 131-167.

[5]. Villabón, O. G. R., Pinzón, J. V., \& Fernández, J. M. R. (2016). La relación entre la responsabilidad social empresarial y el desempeño financiero.: Estado del arte de estudios y metaanálisis. Sotavento MBA, (27), 112-120.

[6]. Carroll, A. B. (1991). The pyramid of corporate social responsibility: Toward the moral management of organizational stakeholders. Business horizons, 34(4), 39-48.

[7]. Johnson, M. P., \& Schaltegger, S. (2016). Two decades of sustainability management tools for SMEs: How far have we come?. Journal of Small Business Management, 54(2), 481-505.

[8]. Peña, R. A. (2018). La educación ambiental, una estrategia adecuada para el desarrollo sostenible de las comunidades. DELOS: Desarrollo Local Sostenible, 11(31), 26.

[9]. Geoffrey, P. L. (2001). The boundaries of strategic corporate social responsibility. Journal of Consumer Marketing, 18(7), 595-632.

[10]. Garriga, E., \& Melé, D. (2004). Corporate social responsibility theories: Mapping the territory. Journal of business ethics, 53(1), 51-71.

[11]. Bernal Vargas, O. M. (2016). Hacia la sostenibilidad cafetera-un análisis de política pública (Master's thesis. Maestría en Estudios Interdisciplinarios sobre Desarrollo).

[12]. Cadena, G. (2001). La sostenibilidad de la caficultura colombiana. En Federación Nacional de Cafeteros. Ensayos sobre Economía cafetera (147-151).

[13]. Valencia, L. M. R. (2013). Mujeres cafeteras y los cambios de su rol tradicional. Sociedad y economía, (24), 71-94.

[14]. Azmat, F., \& Rentschler, R. (2017). Gender and ethnic diversity on boards and corporate responsibility: The case of the arts sector. Journal of Business Ethics, 141(2), 317-336.

[15]. Orozco, Y. V. D., Riaga, C. O., \& Bernal, D. F. V. (2013). Responsabilidad social y equidad de género: análisis de diez organizaciones adheridas al Pacto Global Colombia. Revista Tendencias \& Retos, 18(1), 111-126.

[16]. Hyun, E., Yang, D., Jung, H., \& Hong, K. (2016). Women on boards and corporate social responsibility. Sustainability, 8(4), 300.

[17]. Rao, K., \& Tilt, C. (2016). Board composition and corporate social responsibility: The role of diversity, gender, strategy and decision making. Journal of Business Ethics, 138(2), 327-347.

[18]. Moya, D. M. V., Mafla, P. G. P., \& Luna, J. L. V. (2017). La equidad de género como parte de la responsabilidad social en el mercado laboral de la industria turística del Ecuador. Revista Ibero Americana de Estratégia, 16(4), 23-36.

[19]. Hernández, R., Fernández, C., \& Baptista, P. (2010). Metodología de la. Ciudad de México: Mc Graw Hill, 12, 20. 
[20]. Navia, J. M. A., Plazas, E. R., \& Diaz, Y. C. (2019). Leadership and social responsibility from the perspective of gender. Problems and Perspectives in Management, 17(2), 303.

[21]. Giraldo, O. F. (2010). Campesinas construyendo la utopía: mujeres, organizaciones y agroindustrias rurales. Cuadernos de desarrollo rural, 7(65), 18-18.

[22]. Heidrich, P., \& MacLaren, B. (2015). Hacia una valoración del empoderamiento de la mujer en el sector cafetero. Informe final de investigación. Uniandes, Federación Nacional de Cafeteros, The Conference Board of Canada \& Foreign Affairs Development Canada. Bogotá, Colombia.
[23]. Echeverry, E. G., Rincón, O. I. C., Rodríguez, L. C. B., \& Benítez, C. M. P. (2013). Cadena productiva del café: demanda de trabajo para población vulnerable en el departamento del Quindío. Contexto, 2(1), 1131.

[24]. Burgos, A. (2015). Potencial del sector caficultor en Colombia, Nariño y la importancia de la responsabilidad social para su crecimiento económico. Universidad Militar Nueva Granada. Facultad de Ingeniería. Trabajo de grado para optar al título de Especialista en Gerencia Integral de Proyectos.

[25]. León, I. M. M., Lario, N. A., \& Hernández, M. G. (2011). La influencia del género sobre la responsabilidad social empresarial en las entidades de economía social. REVESCO. Revista de Estudios Cooperativos, (105), 143-172. 